\title{
ON THE COBALT/NICKEL RATIO IN ARABLE SOILS
}

\author{
Osmo Mä́itie \\ Department of Soil Science, Agricultural Research Centre, Helsinki
}

Received February 19, 1962

Cobalt is known to be essential for the nutrition of animals and is nowadays one of the chief trace elements studied in research on the nutrition of cattle. Nickel by contrast, does not belong to the group of the trace nutrients, although it is well known that its enrichment factor from rocks and soils into plants is one of the highest among all the elements.

The relative abundance of these two closely related metals in soils has often been measured for geological purposes. The ratio between the cobalt and nickel contents indicates the parent rocks from which the soil has originated. However, the ratio in the soils may be altered by enrichment from soil humus. For the agriculturalist the cobalt content of arable soils, when expressed as the total amounts of this trace metal present in the soils, seems to have no interpretable meaning. The amounts of readily soluble cobalt are a better indicator of the available content of cobalt and possible deficiency of this element.

A comparison of the total amounts of cobalt with those of nickel, and especially the ratio between these trace metals, will nevertheless give some idea of the cobalt status as a whole even in arable soils.

Geological observations show that in acidic rocks although the contents of both these metals are lower than usual, the ratio between cobalt and nickel, $\mathrm{Co} / \mathrm{Ni}$, is relatively high. This is due to the similar value of the ionic radii of magnesium and nickel (II) ions $(0.78 \mathrm{kX})$, the radius of the divalent cobalt ion being a bit larger $(0.82 \mathrm{kX})(19)$. In acidic rocks the ratio is approximately 1 , and in granites it is over $3(2,11,12,20)$. In basic rocks the $\mathrm{Co} / \mathrm{Ni}$ ratio is always below 1 . Some further values for this ratio in different rocks may be of interest; in hydrolyzate sediments, such as sandstones, shales, and limestones, $\mathrm{Co} / \mathrm{Ni}$ is $<0.50$, whereas in oxidate sediments, such as bog iron ores, cobalt predominates and the ratio 3.25 has been found (8). Both elements are taken up by plants from soils. Analyses show a high enrichment for nickel $(13,14)$. 
Further determinations of cobalt and nickel contents have been reported for peats and plants $(10,21)$, and for arable soils in Finland $(15,16,24,25)$, and there have been several investigations of a similar kind in connection with soil science $(3,4,5,6,7,18,22,23)$. All these reports reveal a comparable occurrence of cobalt and nickel, which is chiefly influenced by the origin of the soil.

\section{Material and methods}

Altogether 375 surface layer soil samples, mostly collected from the local experimental fields and representing almost all the common soil types and agricultural districts of the country, were analysed for total cobalt and nickel by an emission spectrographic method. Part of the same material, which is representative of the fertility levels usual in Finland, has been used in another study carried out at the Department of Soil Science (16).

The method used was a spectrographic one with internal standards as reference samples $(9,17)$. This method, like all the "universal spectrographic methods», covering determination of several elements of different excitation character, is often found to be somewhat inaccurate. Both cobalt and nickel, however, are quite similarly excited in the arc and the influence of varied sample matrices on the analysis is slight. The analysis, even when palladium is used as reference element, gives highly reproducible figures, which are actually the most reliable and accurate in spectrographic soil analysis $(1,17)$. Any methodical errors possibly involved in the analysis of a soil sample are still further decreased when the ratio of these two elements is considered.

The loss on ignition, also used for the interpretation of the results, was found by ashing the pretreated samples at a temperature of $450^{\circ} \mathrm{C}$ in a muffle furnace.

The $\mathrm{pH}$ values of soils were measured potentiometrically from soil-water suspensions (26).

Table 1: The average results of cobalt and nickel determinations from soils of different types.
Soil type
No. of
Co ppm
Ni ppm
$\mathrm{Co} / \mathrm{Ni}$

\begin{tabular}{|c|c|c|c|c|}
\hline Coarse soils: $\ldots \ldots \ldots \ldots \ldots \ldots \ldots$ & 89 & 17 & 27 & 0.63 \\
\hline Moraine - Coarser finesand .... & 30 & 14 & 21 & 0.67 \\
\hline Finer finesand $\ldots \ldots \ldots \ldots \ldots$ & 59 & 18 & 29 & 0.62 \\
\hline Clay soils: $\ldots \ldots \ldots \ldots \ldots \ldots \ldots$ & 110 & 20 & 33 & 0.61 \\
\hline Silt $\quad \ldots \ldots \ldots \ldots \ldots \ldots \ldots \ldots \ldots$ & 21 & 20 & 29 & 0.69 \\
\hline Sandy clay $\ldots \ldots \ldots \ldots \ldots \ldots$ & 22 & 20 & 30 & 0.67 \\
\hline Silty clay $\ldots \ldots \ldots \ldots \ldots \ldots$ & 19 & 18 & 26 & 0.70 \\
\hline Heavy clay $\ldots \ldots \ldots \ldots \ldots \ldots$ & 33 & 20 & 41 & 0.49 \\
\hline Muddy clay $\ldots \ldots \ldots \ldots \ldots \ldots$ & 15 & 23 & 46 & 0.49 \\
\hline Organogenic soils: $\ldots \ldots \ldots \ldots \ldots$ & 176 & 9 & 17 & 0.53 \\
\hline Mould, mud, lake mud ........ & 41 & 11 & 22 & 0.50 \\
\hline Ligno-Carex peat $\ldots \ldots \ldots \ldots$ & 68 & 10 & 18 & 0.56 \\
\hline Carex peat $\ldots \ldots \ldots \ldots \ldots$ & 18 & 8 & 16 & 0.49 \\
\hline Sphagnum-Carex peat $\ldots \ldots \ldots$ & 30 & 8 & 15 & 0.53 \\
\hline Sphagnum peat $\ldots \ldots \ldots \ldots \ldots$ & 19 & 7 & 13 & 0.54 \\
\hline
\end{tabular}




\section{Results and discussion}

The results of the cobalt and nickel analyses are shown in Table 1 and Fig. 1. As is to be expected, the highest amounts of both trace metals are found in clays and fine mineral soils, whilst the total amounts in organogenic soils and particularly in raw peat soils are the lowest.

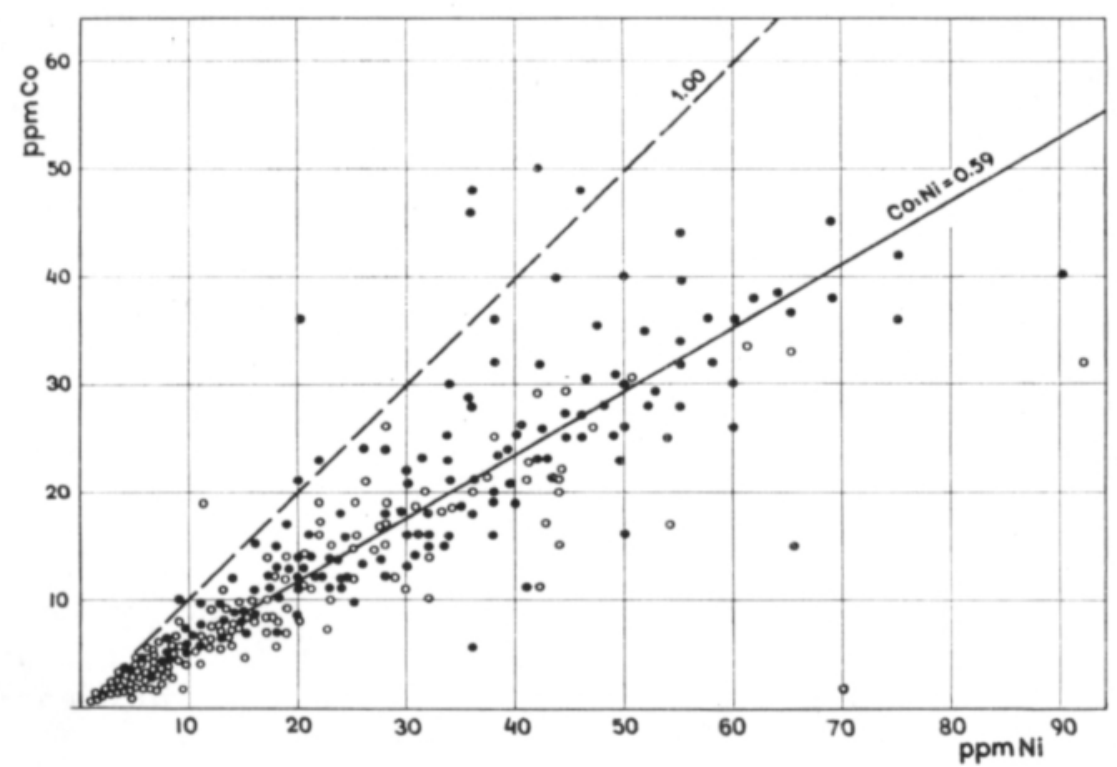

Fig. 1. Comparison of cobalt and nickel contents of arable soils $\mathbf{0}=$ organogenic soils).

A relatively consistent trend is seen when the metal contents are compared with the soil types, (Fig. 2). In mineral soils the cobalt and nickel contents increase from coarse soils towards clays. The average contents in fine clays are about twofold those in finesands. Silty clays form an exception to this order, as is seen from the same figure.

Two separate groups are formed in mineral soils in respect of the cobalt-nickel ratio. Heavy clay and muddy clay show a ratio of about 0.5 , while in the coarse soils it is over 0.6 , the average value being nearly 0.7 .

In the group of different peat soils the ratio shows values between $0.49-0.56$, the lowest value being found in Carex peats. In mould, mud and lake mud soils the average cobalt-nickel ratio is also 0.5 , which is one of the very lowest values of any of the soil types.

In figure 3 , these ratios are plotted against the $\mathrm{pH}$ values of the dried soil samples. It can be seen that the proportion of cobalt tends to rise with increase of $\mathrm{pH}$, although it must be noted that the left part of the curves for the organogenic soils refer to samples of raw Carex and Sphagnum peats, which are generally acid 

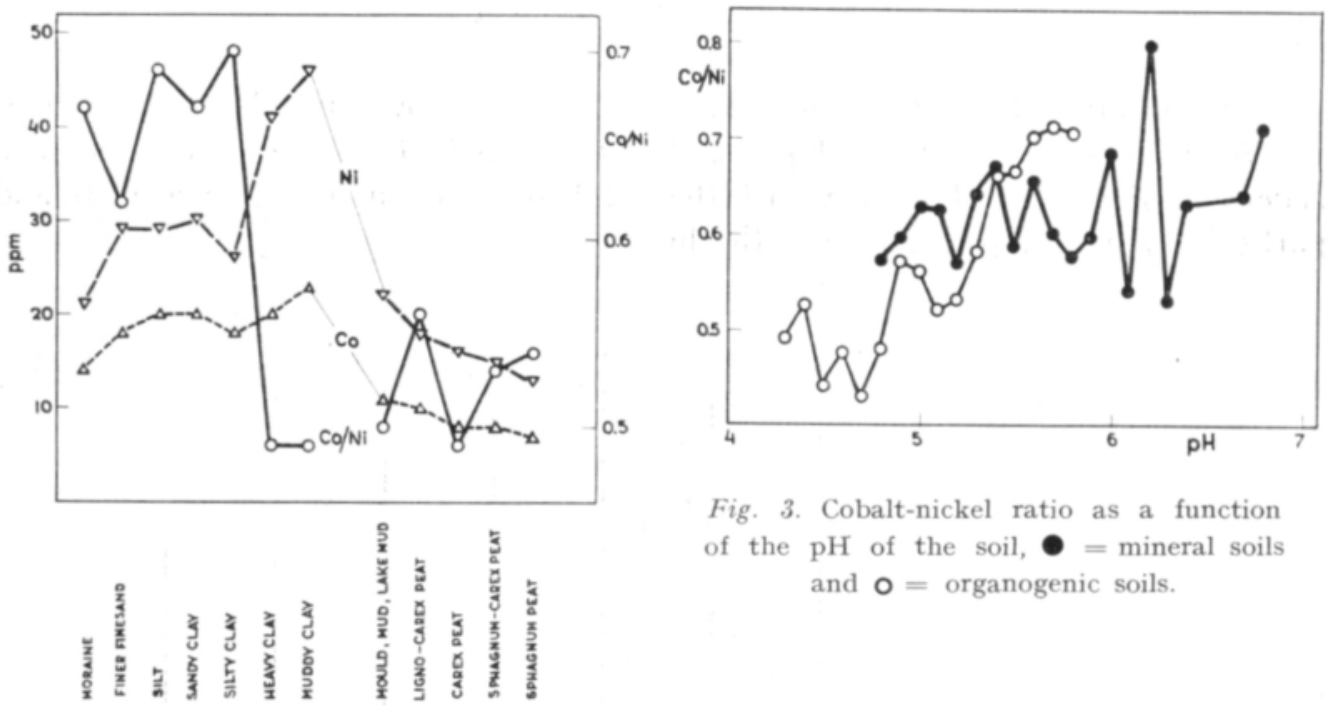

Fig. 2. Cobalt and nickel in different soil types.

and hence had a low ratio initially. The increase of the ratio values is more clearly seen in the organogenic soils than in the mineral soils.

The data provide no accurate measure of the ratio of total cobalt and nickel in these soils, and hence cannot be taken as a basis for far-reaching conclusions. - These experiments show, however, that the ratio between cobalt and nickel is variable and clearly correlated with the soil type as well as with the origin of the soil. Any deviations from the usual values may therefore be due to exceptional circumstances and values that are too low may indicate a soil of poor cobalt status. Such relatively low values are observable, for example, in muddy clays, muds and lake muds, and generally in peat soil types, the very soil types in which cobalt deficiency has mostly been found.

More detailed investigations on the trace element contents of experimental soils may later throw light upon the question of their trace nutrient status compared with that of nearly related trace elements.

\section{REFERENCES}

(1) Ahrens, L. H. \& TAylor, S. R. 1961. Spectrochemical analysis. 454 p. Reading, Mass. USA.

(2) Goldschmidt, V. M. 1954. Geochemistry. 730 p. Oxford.

(3) Grimmet, R. E. R. 1939. Cobalt investigations. N.Z. Dept. Agr. Ann. Rept. 1938-39. 67-71.

(4) Harvey, R. J. 1937. The Denmark Wasting Disease. Cobalt status of some West Australian soils. J. Dept. Agr. W. Australia 14: 386-393.

(5) Hill, A. C. \& Toth, S. J. \& BeAR, F. E. 1953. Cobalt status of New Jersey soils and forage plants and factors affecting the cobalt content of plants. Soil Sci. 76: 273-284.

(6) Kidson, E. B. 1937. Cobalt status of New Zealand soils. N.Z. J. Sci. Techn. 18: 694-707.

(7) - - 1938. Some factors influencing the cobalt contents of soil. J. Soc. Chem. India 57: $95-96$.

(8) Landergren, S. 1948. On the geochemistry of Swedish iron ores and associated rocks. A study on iron-ore formation. Sver. Geol. Undersökn. Ser. C. Avhandl. och Uppsats. No 496. Årsbok. 42 No 5. 
(9) LAPPI, L. \& MÄкıтı́, O. 1954. Quantitative spectrographic determination of minor elements in soil samples. Acta agric. Scand. 5: 69-75.

(10) LounamaA, J. 1956. Trace elements in plants growing wild on different rocks in Finland. Ann. Bot. Soc. 'Vanamo' 29:4, $196 \mathrm{p}$.

(11) Lundegåd, P. H. 1946. Rock composition and development in Central Roslagen, Sweden. Arkiv Kemi. Mineral Geol. 23 A, No 9.

(12) - - 1949. Aspects to the geochemistry of $\mathrm{Cr}, \mathrm{Co}, \mathrm{Ni}$ and $\mathrm{Zn}$. Sver. Geol. Undersökn. Ser. C. No 513.

(13) Maliuga, D. P. 1944. (The problem of Co, Ni and Cu contents of soils. Dokl. Akad. Nauk. SSSR. 43: 207-210.) Ref. Soils \& Fert. VIII:1.

(14) Mrtchell, R. L. 1945. Cobalt and nickel in soils and plants. Soil Sci. 60: 63-70.

(15) Мӓкıтı́, O. 1958. Turvemaiden hivenaineista. (On trace elements in peats). Koetoim. ja käyt. 15: 12.

(16) - 1961. Eräiden hivenaineiden esiintymisestä viljelysmaissamme. (Summary: The occurence of some trace elements in arable soil in Finland.) Agrogeol. publ. 78. 25 p.

(17) - - \& LAPPI, L. 1958. On the effect of matrix composition on the spectrochemical analysis of soil and plant ashes. Ibid. $68: 36 \mathrm{p}$.

(18) Painter, L. I. \& Toth, S. J. \& Bear, F. E. 1953. Nickel status of New Jersey soils. Soil Sci. 76: $421-429$.

(19) Rankama, K. \& Sahama, Th. G. 1950. Geochemistry. 912 p. Chicago.

(20) Sанама, Тн. G. 1945. Spurenelemente der Gesteine im südlichen Finnisch-Lappland. Bull. Comm. Géol. Finlande 135.

(21) Salmi, M. 1950. Turpeiden hivenaineista. (Summary: On trace elements in peat.) Geotechn. publ. 51. $20 \mathrm{p}$.

(22) Scharrer, K. 1955. Biochemie der Spurenelemente. 404 S. Berlin.

(23) Stanton, D. J. 1944. The Co-content of some South Island (New Zealand) limestones. N.Z. J. Sci. Techn. 25 A: $221-224$.

(24) Vuorinen, J. 1958. On the amounts of minor elements in Finnish soils. J. Sci. Agr. Soc. Finl. $30: 30-35$.

(25) $\rightarrow-\quad$ 1960. Hivenaineista Tampereen-Lempäälän seudun maaperässä. (Summary: On the minor element contents of soils in the Tampere-Lempäälä district.) Maatalous ja koetoiminta XIV: $24-36$.

(26) - - \& MÄкıтıе, O. 1955. The method of soil testing in use in Finland. Agrogeol. publ. 63. 44 p.

S E L OS T U S:

KOBOLTTI-NIKKELI SUHTEESTA VILJELYSMAISSA

Osмo MÄкітіЕ

Maantutkimuslaitos, Maatalouden tutkimuskeskus, Helsinki

Tutkimuksessa on käsitelty koboltin ja nikkelin kokonaismäärien suhdetta viljelysmaissa. Aineistona on ollut paikallisten koekenttien maanäytteitä, yhteensä $375 \mathrm{kpl}$ eri puolilta maata, spektrografisesti analysoituina.

On todettu, että koboltin ja nikkelin suhde (piirr. 1.), joka on primäärisesti riippuvainen maalajin alkuperästä, vaihtelee kussakin maalajiryhmässä suhteellisen văhän (taul. 1, piirr. 2). Aito- ja liejusavissa tämä suhde on pienin, n. 0.5. Koboltin ja nikkelin suhde on niinikään rippuvainen jonkin verran maan happamuudesta etenkin turvemaissa (piirr. 3.).

Tarkkaillen näiden hivenmetallien suhdetta maassa voitaneen arvostella koboltin mäărää ja riittoisuutta hivenravinteena. Yleensä kobolttia on suhteellisesti vähiten eloperäisissä maissa ja hienojakoisissa kivennäismaissa. 